\title{
El pensamiento de Luis Carlos Galán sigue vigente a 30 años de su ausencia física
}

Gustavo Zafra Roldán ${ }^{1}$
Pontificia Universidad Javeriana, Colombia
gzafra@javeriana.edu.co

Luis Carlos Galán, fiel a su consigna "los hombres se eliminan los ideales no" ${ }^{[1]}$, dejó un legado histórico que quienes lo conocimos y admiramos todavía reconocemos como la utopía de una Colombia posible. El cumplió la ruta del jesuita que tanto lo inspiró, Pierre Teilhard de Chardin, quien nos dijo "sólo aspiro a dejar la huella de una vida lógica tendida siempre hacia las grandes esperanzas del mundo" ${ }^{[2]}$. A fe que lo hizo.

Fue defensor de la educación pública desde su temprano trabajo en el Ministerio de Educación, apoyando proyectos desde los niveles de infancia, primaria, media y universitaria, y enseñando con el ejemplo en casa, donde sus hijos asistieron a colegios públicos. A nivel de la educación superior trabajó por la universidad privada y pública comprometido con la igualdad social, sin perjuicio de su autonomía.

Debido a su concepción cepalina, influencia de Carlos Lleras Restrepo y Raúl Prebish, lo llevó a formular la integración latinoamericana, el libre comercio latino, la apertura al multilateralismo como convivencia en un mundo global, que había reforzado con su estadía en la Embajada en Italia, en donde profundizó en el estudio del tratado de Roma de 1957 y en la obra de Segni, De Gaspiere, Spack, Shumman y Monett los creadores intelectuales de la Unión Europea.

Desde su amor entrañable por el Estado hermano de Venezuela y su última visita internacional a tres semanas del magnicidio.

Desde su convicción sobre la necesaria democratización de los partidos que encarna en la consulta popular para la escogencia de los candidatos a la presidencia. Tarea que permitió la séptima papeleta, la convocatoria de la Constituyente en 1991 en la posta entregada por Luis Carlos Galán en 1989 al gobernante de los años 90.

Desde su compromiso con los entonces 1109 municipios de Colombia a los que empoderó tributariamente con las ponencias de la ley 14 de 1983 y la ley 12 de 1986 con sus generales económicos Ernesto Rojas, Gabriel Rosas e Iván Marulanda entre otros, coliderando esta última con el senador Víctor Renán Barco.

Desde su formidable debate como Senador en el caso del carbón del Cerrejón, donde premonitoriamente anticipó los escenarios de costos ambientales sin un sistema compensatorio suficiente en impuestos y regalías.

Desde su amor por la Bogotá de la cual fue concejal, con la preocupación de una tributación predial adecuada y equitativa, que sólo se logró con la ley 1995 de 2019 que había anticipado y pergeñado desde la ley 14 de 1983 con los catastros justos.

Desde su visión de la ética en la política que lo llevó a expulsar de su movimiento al mayor delincuente internacional del narcotráfico.

Desde su compromiso con una prensa libre, sin censura, que practicó al lado de quien fue su esposa Gloria Pachón y de dos gigantes del periodismo independiente Daniel Samper Pizano y Enrique Santos Calderón.

¿Dónde estaría hoy Luis Carlos Galán en los grandes temas de la Colombia?

Con generosidad, sin duda alguna, estaría ayudando a concluir bien el proceso de paz con los insurgentes desmovilizados, y con sentido de Estado estaría también enfrentando la delincuencia, dentro del imperio de la ley y con una visión de corresponsabilidad internacional de los Estados involucrados, sin recriminaciones.

Notas de autor

\footnotetext{
${ }^{1}$ Editor Invitado
} 
Con grandeza, estaría abriendo espacios para el diálogo en tiempo oportuno, con los reductos de insurgencias anacrónicas.

Con convicción de hombre de letras, estaría auspiciando espacios de pluralismo en los medios de comunicación, sin persecuciones económicas ni políticas a los contendores intelectuales.

Con hermandad latinoamericana, estaría buscando una salida diplomática al drama de Venezuela, respetuoso de la autodeterminación, en la línea del Estado Vaticano, de Uruguay y México.

Y, sobre todo, no estaría en ningún club de expresidentes a los cuales su "Élan" vital era ajeno.

\section{Notas}

[1] Frase que dijo en su última visita a Venezuela, quince días antes de su magnicidio.

[2] Esta cita de Teilhard aparece en el epígrafe de las conferencias mimeografiadas de 1968, publicadas por la Universidad Javeriana.

Licencia Creative Commons CC BY 4.0

Para citar este editorial / To cite this editorial: Gustavo Zafra Roldán, El pensamiento de Luis Carlos Galán sigue vigente a 30 años de su ausencia física, 68 Vniversitas, n. 139 (2019). https://doi.org/10.11144/Javer iana.vj139.plcg 